\title{
Isolation, Identification and Degradation Characteristics of Oil Degrading Bacterial Strain
}

\author{
Yabin Zhan1, Xingling Tao1, Shanwen Heㄹ, Shufen Song1, Jingjing Xing1, Fangmin Li², \\ Tao Jiang ${ }^{3}$, Lian Ma $^{{ }^{*}}$ \\ ${ }^{1}$ College of Life Science, Yangtze University, Jingzhou, China \\ ${ }^{2}$ College of Chemical and Environmental Engineering, Yangtze University, Jingzhou, China \\ ${ }^{3}$ College of Animal Science, Yangtze University, Jingzhou, China \\ Email: 1766784675@qq.com, *jiangtao@yangtzeu.edu.cn, *malian@yangtzeu.edu.cn
}

How to cite this paper: Zhan, Y.B., Tao, X.L., He, S.W., Song, S.F., Xing, J.J., Li F.M., Jiang, T. and Ma, L. (2017) Isolation, Identification and Degradation Characteristics of Oil Degrading Bacterial Strain. Open Access Library Journal, 4: e4016. https://doi.org/10.4236/oalib.1104016

Received: October 10, 2017

Accepted: October 24, 2017

Published: October 27, 2017

Copyright $\odot 2017$ by authors and Open Access Library Inc.

This work is licensed under the Creative Commons Attribution International License (CC BY 4.0).

http://creativecommons.org/licenses/by/4.0/

\begin{abstract}
Objective: The aim of study is to obtain a strain which can effectively degrade oil. Methods: By enrichment, domestication and separation of culture from the sample which comes from Qianjiang Guanghua Oilfield, the pure culture (G-40) was selected from the medium supplemented with oil as the sole source of carbon. The G-40 was preliminarily identified and classified by morphological observation, physiological and biochemical determination and sequence analyses of $16 \mathrm{~S}$ rDNA. Effects of temperature, $\mathrm{pH}$, oil concentration, salt concentration, inoculation amount, $\mathrm{N}$ and $\mathrm{P}$ source on the degradation of the oil were studied by single factor test. Meanwhile, the effects of temperature, $\mathrm{pH}$, oil concentration and salt concentration were optimized by orthogonal design. Result: G-40 was isolated and identified as Brevibacillus laterosporus. The orthogonal design showed that the degradation rate of oil could reach $20.81 \%, 24.34 \%$ and $31.15 \%$ at $10 \mathrm{~d}, 20 \mathrm{~d}$ and $40 \mathrm{~d}$ under the optimal conditions which was $35^{\circ} \mathrm{C}$, initial $\mathrm{pH} 7.3$, oil concentration $0.6 \%$, salt concentration $0.5 \%$, inoculum amount $8 \%$, the optimal $\mathrm{N}$ and $\mathrm{P}$ was $\left(\mathrm{NH}_{4}\right)_{2} \mathrm{SO}_{4}$ and $\mathrm{K}_{2} \mathrm{HPO}_{4}$. Conclusion: This study provides microbial resources for bioremediation of petroleum contaminated soil.
\end{abstract}

\section{Subject Areas \\ Environmental Sciences}

\section{Keywords}

Degrading Bacteria, Brevibacillus Laterosporus, Oil Degrading 


\section{Introduction}

Release of hydrocarbon into the environment whether accidentally or due to human activities is a main cause of water and soil pollution [1] [2]. Soil contamination with hydrocarbons causes extensive damage of local system since accumulation of pollutants in animals and plant tissue may cause death or mutations [3]. From the environment, hydrocarbon can also enter in food chains, leading to health problems. In the body, PAH are mutagenic and can cause a decrease in the immune response with an increased risk of infections [4].

Fortunately, the degradation of these oils in the environment is possible through several techniques: physical [5], chemical [6] or biological [7]. The technology commonly used for the soil remediation includes mechanical, burying, evaporation, dispersion and washing. However, these technologies are expensive and can lead to incomplete decomposition of contaminants. The process of bioremediation, defined as the use of microorganisms to detoxify or remove pollutants owing to their diverse metabolic capabilities is an evolving method for the removal and degradation of many environmental pollutants including the products of petroleum industry [8]. In addition, bioremediation technology is believed to be noninvasive and relatively cost-effective [9]. Biodegradation by natural population of microorganisms represents one of the primary mechanisms by which petroleum and other hydrocarbon pollutants can be removed from the environment and is cheaper than other remediation technologies and the most efficient for environment safe depollution [10] [11].

Thus, in order to get insight of the bioremediation process of hydrocarbon in Qianjiang Guanghua Oilfield, the present study focused on the isolation, identification and degradation characterization of indigenous hydrocarbon-degrading bacterial strains with regards to the conditions for optimizing their activities and the efficient cleanup of the hydrocarbon pollutants.

\section{Materials and Methods}

\subsection{Source of Isolation}

The source for bacterial isolation consisted of soil contaminated with oil. Soil samples were collected into $500 \mathrm{ml}$ sterilized glass bottles from eight sites in Qianjiang Guanghua Oilfield on June 2015, immediately carried to the laboratory and stored in a refrigerator prior at $4^{\circ} \mathrm{C}$ to use.

\subsection{Media}

Oil medium ( $0.5 \%$ oil) according to reference [12].

Beef peptone liquid medium, beef peptone solid medium, according to reference [13].

\subsection{Isolation of Bacteria}

Five gram oil contaminated soil sample was inoculated in the $250 \mathrm{ml}$ erlenmeyer flask of $100 \mathrm{ml}$ oil medium on a horizontal shaker $(150 \mathrm{rpm})$ at $35^{\circ} \mathrm{C}$. After 5 
days incubation period, $5 \mathrm{ml}$ of sample from primary enrichment medium was transferred to a fresh oil medium containing the same oil and incubated as above. After three subculturing steps in broth medium, $0.1 \mathrm{ml}$ of enrichment culture was plated after appropriate dilution on beef peptone solid medium and incubated at $37^{\circ} \mathrm{C}$ for $24 \mathrm{~h}$. Single colony appeared on the beef peptone solid medium was translated on a fresh beef peptone solid medium and incubated. Pure colony was obtained by using a single colony isolation procedure. Isolated colony was stored at $4^{\circ} \mathrm{C}$ on beef peptone solid medium and subcultured at 3-week intervals or mixed with $40 \%$ glycerol and stored at $-80^{\circ} \mathrm{C}$ for future utilization [12].

\subsection{Growth Study}

Experiments were conducted in the liquid MS medium described above with $0.5 \%$ oil (w/v) as sole carbon and energy source. Growth was monitored by measuring optical density at $420 \mathrm{~nm}$ with a TU-1900 spectrophotometer [14].

\subsection{Determination of Petroleum Degradation Rate}

The rate of oil degradation was determined by gravimetric method. A total of 80 $\mathrm{ml}$ methylene chloride was added to the oil triangle bottle to extract the oil. The water in the oil was dried at room temperature until the anhydrous sodium sulfate column was removed, until the organic solvent completely evaporated. Place the oil in the vacuum drying box at $40^{\circ} \mathrm{C}$ and keep the vacuum at $0.04 \mathrm{Mpa}$ for $30 \mathrm{~min}$. Then remove it and leave it in the dryer for $30 \mathrm{~min}$ and to weigh. The rate of petroleum degradation is calculated according to the Formula (1):

$$
D=\frac{\left(C_{0}-C_{s}\right)}{C_{0}} \times 100 \%
$$

$D$ : The rate of petroleum degradation, \%; $C_{0}$ : blank hydrocarbon concentration, $\mathrm{mg} / \mathrm{L} ; C_{\dot{S}}$ concentration of petroleum hydrocarbon in the culture fluid, $\mathrm{mg} / \mathrm{L}$ [15].

\subsection{Taxonomy}

\subsubsection{Culture Characteristics and Cell Morphology}

The colony characteristics were observed on the agar plate of Beef Peptone Agar, and the cell morphology was observed under microscope after gram staining.

\subsubsection{Physiological and Biochemical Tests}

The physiological and biochemical properties of the strain were determined according to the microbiological test method [13].

\subsubsection{Molecular Biological Assay}

The16S rDNA gene of colony G-40 was amplified by PCR using the universal primers 27F and 1492R [16] and Thermo Scientific Phusion Flash High-Fidelity kit. The 16S rDNA gene were sequenced by Sangon Biotech (Shanghai, China) Co., Ltd. The sequence similarities were analysed by Blasting on the National Centre for Biotechnology Information (NCBI). The phylogenetic tree was con- 
structed by software MEGA5.0.

\subsection{Study on Degradation Characteristics}

\subsubsection{Single Factor Test}

The bacteria were inoculated into beef peptone liquid medium. The bacteria were inoculated in logarithmic phase, centrifuged, removed supernatant, washed with sterile normal saline, and adjusted to $\mathrm{OD}_{420}=3.28$. In the basic culture medium at the same time, by changing the growth conditions in different temperature, $\mathrm{pH}$, oil concentration, salt concentration, inoculation amount, $\mathrm{N}$ source, $\mathrm{P}$ source on a horizontal shaker $(150 \mathrm{rpm})$ at $35^{\circ} \mathrm{C}$ in $100 \mathrm{ml}$ oil medium for $5 \mathrm{~d}$. Learning the suitable growth conditions of $\mathrm{G}-40$ by the determination of $\mathrm{OD}_{422}$.

\subsubsection{Orthogonal Test}

Four factors and 3 levels orthogonal test (Table 1) was carried out with temperature, $\mathrm{pH}$ and oil concentration and salt concentration. With $8 \%$ inoculation on a horizontal shaker $(150 \mathrm{rpm})$ in $100 \mathrm{ml}$ oil medium for $5 \mathrm{~d}$. Learning the optimum growth condition of G- 40 by the determination of $\mathrm{OD}_{420}$.

\subsubsection{Verification Test}

Under orthogonal optimum conditions, the oil removal rate of G-40 was measured at 10, 20 and 40 day, respectively.

\subsection{Determination of Growth Curve}

Under the optimum conditions, the strain of G-40 was injected into the oil medium with $8 \%$ inoculum, drawing the growth curve by measuring its $\mathrm{OD}_{422}$.

\section{Results and Analysis}

\subsection{The Results of Taxonomy}

\subsubsection{Culture Characteristics and Cell Morphology}

A strain of G-40 which can remove oil isolated from contaminated soil. After 3 days of cultivation of bacteria, colony morphology is shown in Figure 1. A few selected bacteria were Gram staining, showed that bacteria were $\mathrm{G}^{+}$, spores are oval, lateral; The characteristics of colonies are shown in Table 2.

Table 1. Factor levels table.

\begin{tabular}{ccccc}
\hline & $\mathrm{A}\left({ }^{\circ} \mathrm{C}\right)$ & $\mathrm{B}$ & $\mathrm{C}(\%)$ & $\mathrm{D}(\%)$ \\
\hline 1 & 30 & 7.3 & 0.4 & 0.3 \\
2 & 33 & 7.5 & 0.5 & 0.4 \\
3 & 35 & 7.7 & 0.6 & 0.5 \\
\hline
\end{tabular}

A: Temperature; B: pH; C: oil concentration; D: salt concentration.

Table 2. Morphology and culture characteristics of strain G-40.

\begin{tabular}{ccccccc}
\hline Morphology & Colour & Texture & Protuberance & Edge & Diameter $(\mathrm{mm})$ & Area $\left(\mathrm{mm}^{2}\right)$ \\
\hline Circular & Beige & Smooth & Convex lens & Integrity & 2.01 & 3.13 \\
\hline
\end{tabular}



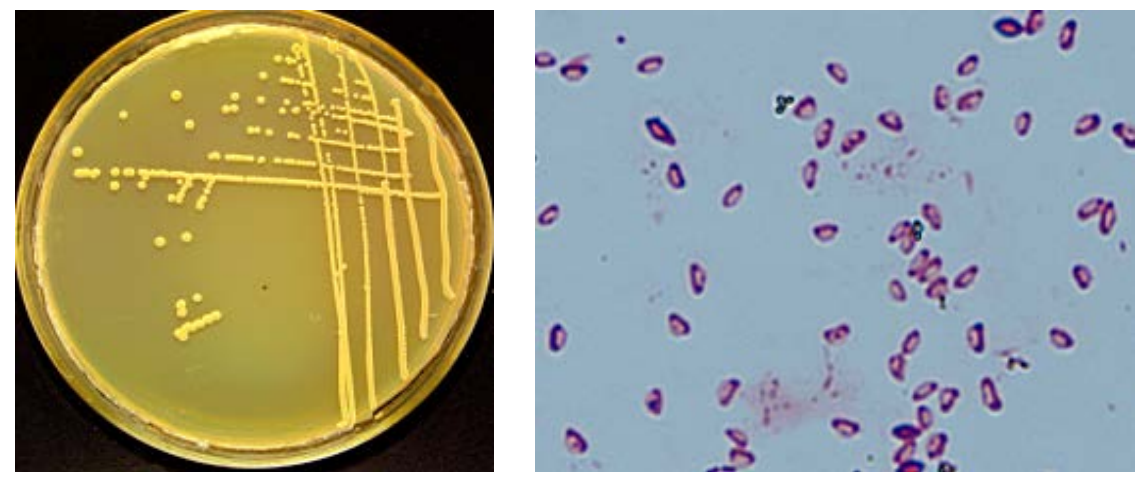

Figure 1. Morphological of G-40 $(10 \times 100)$.

\subsubsection{Physiological and Biochemical}

The physiological and biochemical of G-40 is shown in Table 3. Combined with culture characteristics and cell morphology, according to Berger's Manual of Determinative Bacteriology, the strain can be identified as Brevibacillus [17].

\subsubsection{Molecular Identification}

The 16S rDNA gene obtained from the isolates was amplified via PCR using a universal bacterial primer set. Based on the morphological observation, physiological and biochemical determination and sequence analyses of $16 \mathrm{~S}$ rDNA sequence, the G-40 was identified as Brevibacillus laterosporus. The 16S rDNA sequence date have been deposited in the GenBank database under the accession numbers KY949476. The phylogenetic tree of G-40 showed as Figure 2.

\subsection{Physiology}

\subsubsection{Single Factor Test}

\section{1) Temperature}

The biomass of G-40 was effected by temperature as shown in Figure 3. The biomass increased firstly and decreased lastly with the increase of temperature. There were larger biomass of G-40, when the temperature were $30^{\circ} \mathrm{C}\left(\mathrm{OD}_{420}=\right.$ $0.655)$ and $35^{\circ} \mathrm{C}\left(\mathrm{OD}_{420}=0.557\right)$. Compared with other treatments, there were significant differences.

Extremely significant difference $(P<0.01)$; Significance difference $(P<0.05)$. Same as below.

\section{2) $\mathrm{pH}$}

The biomass of G-40 effected by $\mathrm{pH}$ as shown in Figure 4. The biomass increased firstly and decreased lastly with the increase of $\mathrm{pH}$. There was larger biomass of $\mathrm{G}-40$, when the $\mathrm{pH}$ was $7.5\left(\mathrm{OD}_{420}=0.699\right)$. Compared with other treatments, there were extremely significant differences.

\section{3) Oil Concentration}

The biomass of G-40 effected by oil concentration as shown in Figure 5. There were larger biomass of G-40, when the oil concentration were $0.4 \%\left(\mathrm{OD}_{420}\right.$ $=0.669), 0.6 \%\left(\mathrm{OD}_{420}=0.719\right), 0.8 \%\left(\mathrm{OD}_{420}=0.615\right), 1.0 \%\left(\mathrm{OD}_{420}=0.644\right)$. Compared with the biomass of oil concentrate $0.2 \%$, there were extremely significant differences. 


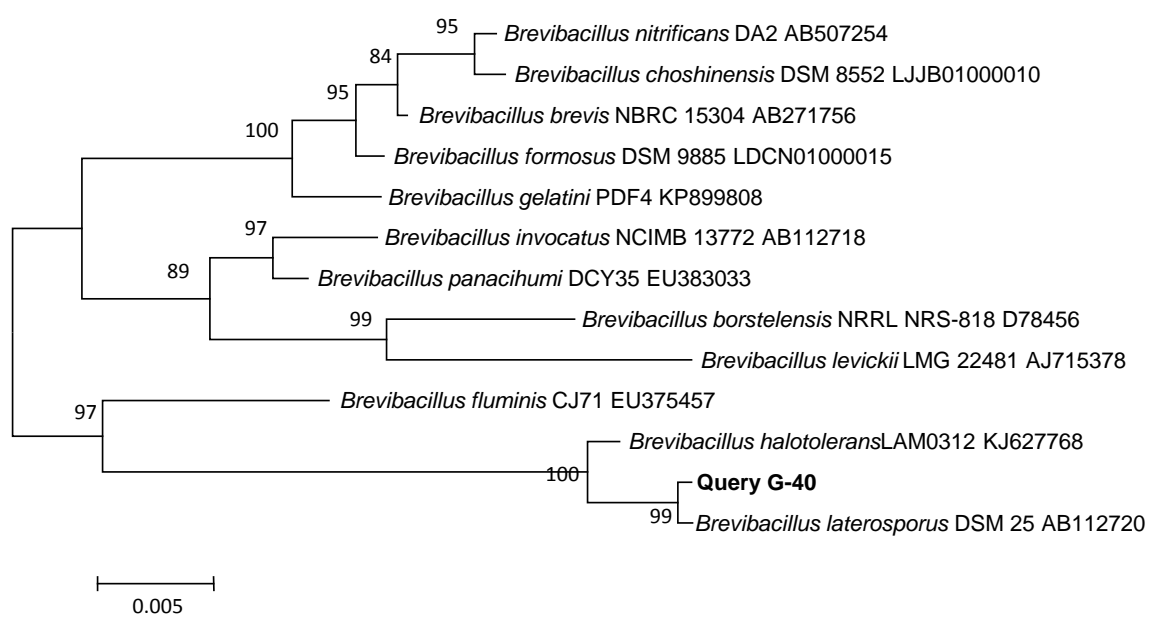

Figure 2. Neighbor-joining phylogenetic tree constructed from $16 \mathrm{~S}$ rDNA gene sequence of G-40.

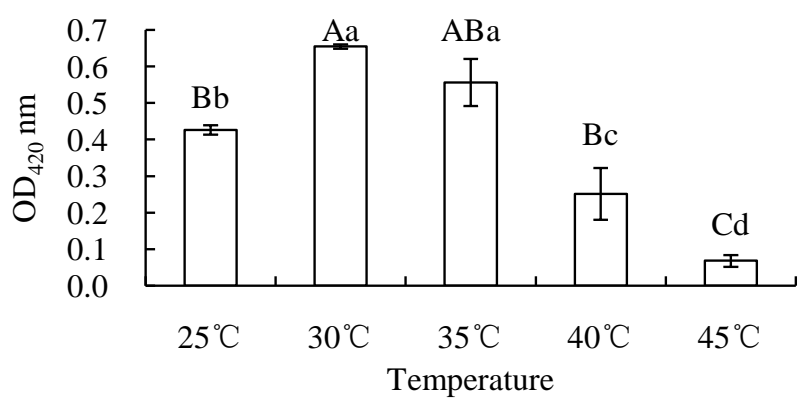

Figure 3. Biomass of G-40 under different temperature.

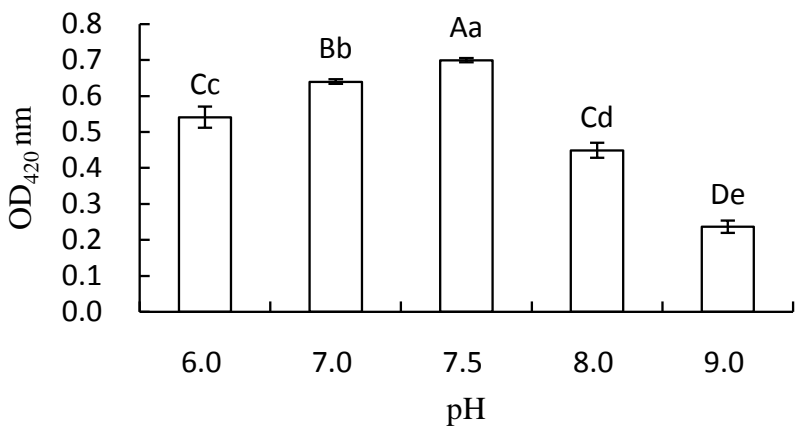

Figure 4. Biomass of G-40 under different $\mathrm{pH}$.

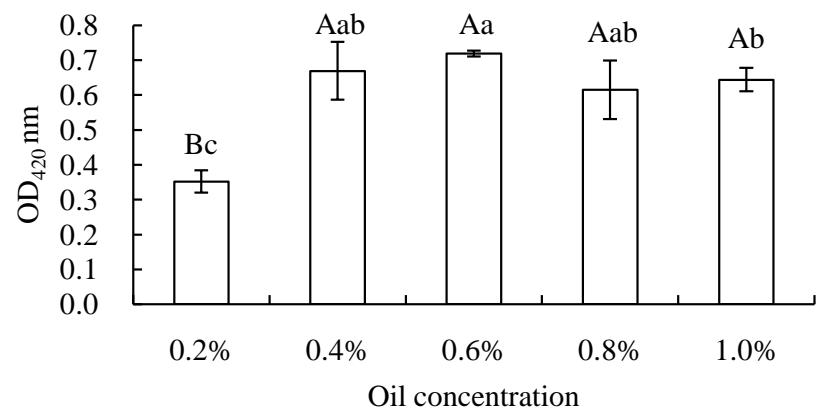

Figure 5. Biomass of G-40 under different oil concentration. 
Table 3. Biophysiological-biochemical characters of the Strain G-40.

\begin{tabular}{cccc}
\hline Test item & Result & Test item & Result \\
\hline Gelatin liquefaction & + & Starch hydrolysis & - \\
Indole & + & Lipid hydrolysis & - \\
$\mathrm{H}_{2} \mathrm{O}_{2}$ & + & Ammonia production & + \\
Citrate & + & Nitrate reduction & - \\
M.R. & + & Phenylalanine dehydrogenase & + \\
V.P. & - & $\mathrm{H}_{2} \mathrm{~S}$ & + \\
\hline
\end{tabular}

+: positive, -: negative.

\section{4) Salinity}

The biomass of G-40 effected by salt concentration as shown in Figure 6. The biomass increased firstly and decreased lastly with the increase of salt concentration. There were larger biomass of G-40, when the salt concentration were $0.2 \%$ $\left(\mathrm{OD}_{420}=0.482\right)$ and $0.4 \%\left(\mathrm{OD}_{420}=0.569\right)$. Compared with other treatments, there were extremely significant differences.

\section{5) Inoculation amount}

The biomass of G-40 effected by inoculation amount as shown in Figure 7. The biomass increased with the increase of inoculation amount. There were larger biomass of G-40, when the inoculation amount were $8 \%\left(\mathrm{OD}_{420}=0.972\right)$ and $10 \%\left(\mathrm{OD}_{420}=1.036\right)$. Compared with other treatments, there were extremely significant differences.

\section{6) Nitrogen}

The biomass of G-40 effected by nitrogen source as shown in Figure 8. There were larger biomass of G-40, when the nitrogen source were $\left(\mathrm{NH}_{4}\right)_{2} \mathrm{SO}_{4}\left(\mathrm{OD}_{420}=\right.$ $0.593), \mathrm{NH}_{4} \mathrm{Cl}\left(\mathrm{OD}_{420}=0.538\right)$ and $\mathrm{NH}_{4} \mathrm{NO}_{3}\left(\mathrm{OD}_{420}=0.500\right)$. Compared with the biomass of $\mathrm{KNO}_{3}$, there were extremely significant differences.

\section{7) Phosphorus}

The biomass of G-40 effected by phosphorus source as shown in Figure 9. There were larger biomass of G-40, when the phosphorus source were $\mathrm{K}_{2} \mathrm{HPO}_{4}$ $\left(\mathrm{OD}_{420}=0.515\right)$ and $\mathrm{Na}_{2} \mathrm{HPO}_{4}\left(\mathrm{OD}_{420}=0.534\right)$. Compared with the biomass of $\mathrm{KH}_{2} \mathrm{PO}_{4}$ and $\mathrm{NaH}_{2} \mathrm{PO}_{4}$, there were extremely significant differences.

\subsubsection{Orthogonal Test}

Different conditions had obvious influence on the oil removal rate of G-40. The maximum range of temperature is the key factor affecting the oil removal rate of G-40, followed by $\mathrm{pH}$ and oil concentration, while salt concentration has the least influence. Therefore, the suitable condition of oil removal rate of G-40 was $\mathrm{A}_{3} \mathrm{~B}_{1} \mathrm{C}_{3} \mathrm{D}_{3}$ which was $35^{\circ} \mathrm{C}, \mathrm{pH} 7.3$, oil concentration $0.6 \%$, salt concentration $0.5 \%$ (Table 4).

\subsubsection{Verification Test}

The results of verification test were shown in Figure 10. Under orthogonal optimum conditions, the oil degradation of G-40 reached to $20.81 \%, 24.34 \%$ and $31.15 \%$ at 10,20 and 40 day, respectively. 


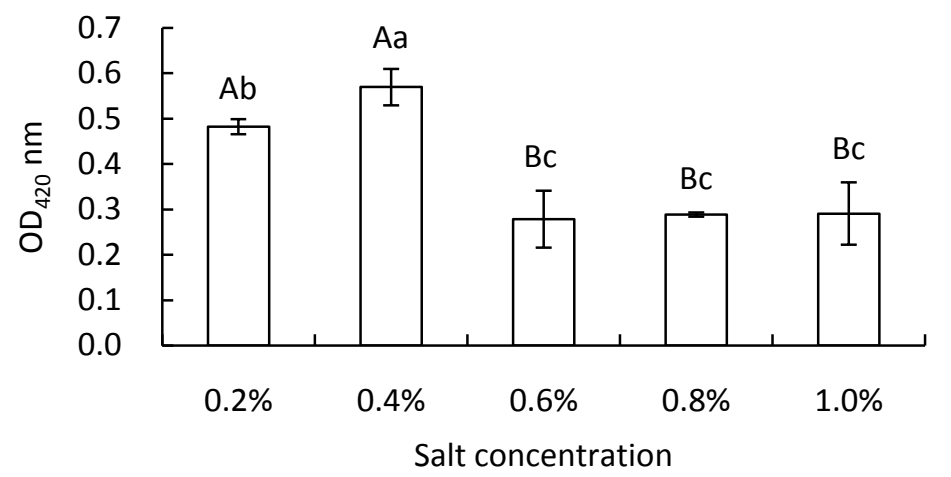

Figure 6. Biomass of G-40 under different salt concentration

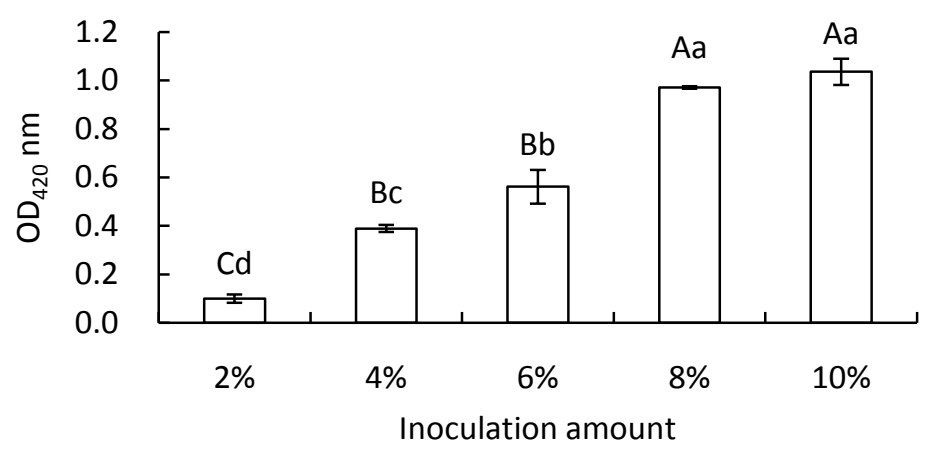

Figure 7. Biomass of G-40 under different inoculation amount.

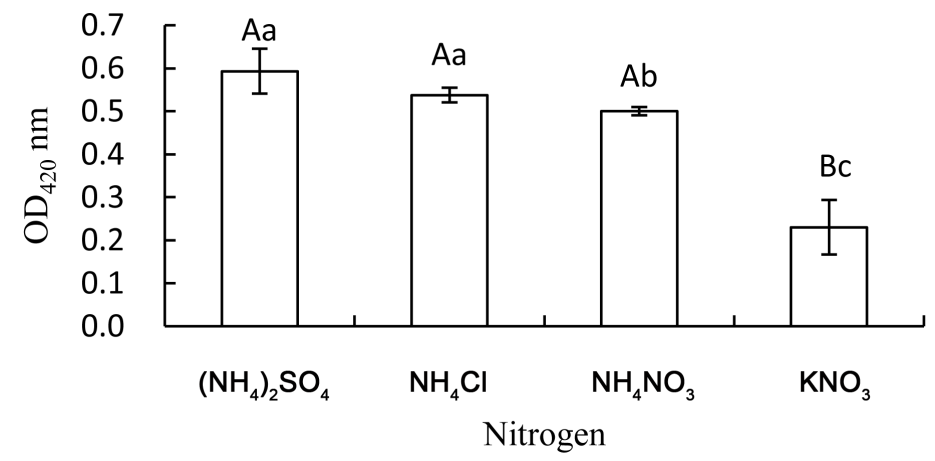

Figure 8. Biomass of G-40 under different nitrogen source.

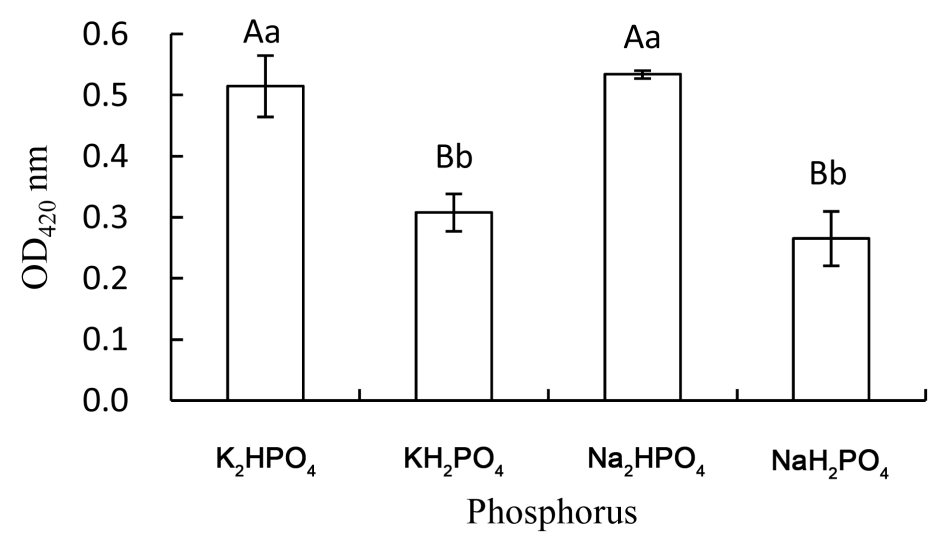

Figure 9. Biomass of G-40 under different phosphorus source. 


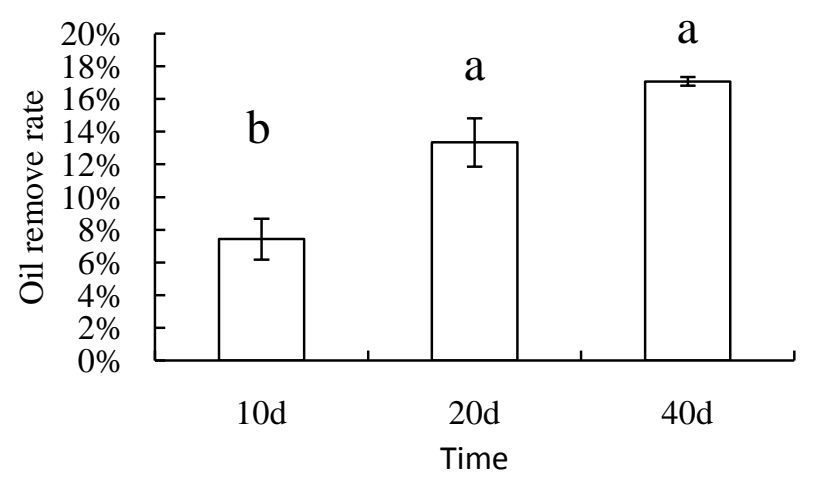

Figure 10. Oil degradation rate of strain G-40 on different

Table 4. The orthogonal design and analysis of G-40.

\begin{tabular}{cccccc}
\hline Treatment & $\mathrm{A}\left({ }^{\circ} \mathrm{C}\right)$ & $\mathrm{B}$ & $\mathrm{C}(\%)$ & $\mathrm{D}(\%)$ & Result \\
\hline 1 & 30 & 7.3 & 0.4 & 0.3 & 0.580 \\
2 & 30 & 7.5 & 0.5 & 0.4 & 0.531 \\
3 & 30 & 7.7 & 0.6 & 0.5 & 0.487 \\
4 & 33 & 7.3 & 0.5 & 0.5 & 0.848 \\
5 & 33 & 7.5 & 0.6 & 0.3 & 0.847 \\
6 & 33 & 7.7 & 0.4 & 0.4 & 0.554 \\
7 & 35 & 7.3 & 0.6 & 0.4 & 1.080 \\
8 & 35 & 7.5 & 0.4 & 0.5 & 0.937 \\
9 & 35 & 7.7 & 0.5 & 0.3 & 0.798 \\
$\mathrm{~K} 1$ & 0.533 & 0.836 & 0.689 & 0.742 & \\
$\mathrm{~K} 2$ & 0.750 & 0.771 & 0.726 & 0.722 & \\
$\mathrm{~K} 3$ & 0.937 & 0.613 & 0.805 & 0.756 & \\
$\mathrm{R}$ & 0.404 & 0.223 & 0.116 & 0.034 & \\
\hline
\end{tabular}

A: Temperature; B: pH; C: Oil concentration; D: Salt concentration.

\subsection{Determination of Growth Curve}

The results of Determination of growth curve were shown in Figure 11. The 0 1 day was the lag phase of G-40; In this period, the reason why no biomass increase is that bacteria were first introduced into a fresh media. The $2-11$ day was the exponential of G-40; In this period, the strain rapidly propagated and gradually turned the oil medium to muddy. The $12-18$ day was the stationary phase of G-40; In this period, death rate = rate of reproduction of G-40 and continues for a long time.

\section{Discussion and Conclusion}

\subsection{Discussion}

Brevibacillus laterosporus was identified by Shida [18] through construction of phylogenetic tree of $16 \mathrm{~S}$ rDNA gene sequence analysis and Bacillus system in 1996. Based on the morphological observation, physiological and biochemical 


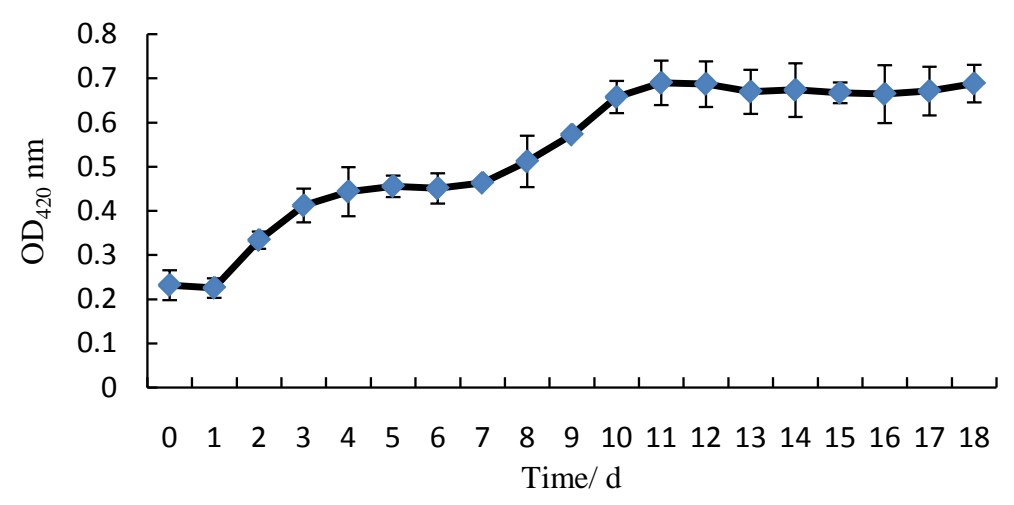

Figure 11. The growth curve of G-40 under the optimal conditions.

determination and sequence analyses of $16 \mathrm{~S}$ rDNA sequence, the G-40 was identified as Brevibacillus laterosporus.

A strain of G-40 with petroleum as the sole carbon source was isolated from the soil contaminated by petroleum for a long time. The effects of temperature, $\mathrm{pH}$, oil concentration, salt concentration, inoculum amount, $\mathrm{N}$ and $\mathrm{P}$ source on the degradation of oil were studied. Different conditions had great influences on the oil removal rate of G-40. The G- 40 has larger biomass when the inoculation amount was $10 \%\left(\mathrm{OD}_{420}=1.036\right)$; Compared with the inoculation amount of $8 \%$ (0.972), there was no significant differences; Finally, the inoculation amount $8 \%$ was used to do the orthogonal experiment. The optimum $\mathrm{N}$ and $\mathrm{P}$ source was $\left(\mathrm{NH}_{4}\right)_{2} \mathrm{SO}_{4}$ and $\mathrm{K}_{2} \mathrm{HPO}_{4}$, which is basically consistent with the MS medium. Therefore, the temperature, $\mathrm{pH}$ and oil concentration and salt concentration were selected to do orthogonal test to further study the optimum conditions for degrading oil.

The oil removal rate of G-40 reached to $20.81 \%$ on 10 th day. The oil removal rate of G-40 reached $24.34 \%$ on 20 th day, increased by $16.96 \%$ compared with 10th day. The oil removal rate of G-40 reached $31.15 \%$ on 40 th day, increased by $27.98 \%$ compared with 20th day. Maybe, the nutrition in the bottle had been consumed with the passage of time, the degradation rate of increase was not obvious. In order to improve the oil removal rate, nutrition can be added to the bottle.

Oil degradation is limited by many factors in the soil [14] [19] [20]. The development and utilization of the genetic resources of G-40 bacteria for petroleum degradation and their application in the remediation of petroleum contaminated soils should be further studied.

\subsection{Conclusion}

The suitable conditions of oil removal rate of $\mathrm{G}-40$ were $35^{\circ} \mathrm{C}, \mathrm{pH} 7.3$, oil concentration $0.6 \%$, salt concentration $0.5 \%$, inoculation amount $8 \%, \mathrm{~N}$ and $\mathrm{P}$ was $\left(\mathrm{NH}_{4}\right)_{2} \mathrm{SO}_{4}$ and $\mathrm{K}_{2} \mathrm{HPO}_{4}$. Under orthogonal optimum conditions, the oil removal rate of G-40 reached to $20.81 \%, 24.34 \%$ and $31.15 \%$ on the 10 th, 20 th and 40 th day, respectively. 


\section{References}

[1] Holliger, C., Gaspard, S., Glod, G., Heijman, C., Schumacher, W., Schwarzenbach, R.P. and Vazquez, F. (1997) Contaminated Environments in the Subsurface and Bioremediation, Organic Contaminants. Fems Microbiology Reviews, 20, 517-523. https://doi.org/10.1111/j.1574-6976.1997.tb00334.x

[2] Das, N. and Chandran, P. (2011) Microbial Degradation of Petroleum Hydrocarbon Contaminants: An Overview. Biotechnology Research International, 2011, Article ID: 941810. https://doi.org/10.4061/2011/941810

[3] Alvarez, P.J. and Vogel, T.M. (1991) Substrate Interactions of Benzene, Toluene, and Para-Xylene during Microbial Degradation by Pure Cultures and Mixed Culture Aquifer Slurries. Applied and Environmental Microbiology, 57, 2981-2985.

[4] Ma, J., Yan, G.X., Ma, W.F., Cheng, C.M., Wang, Q.G. and Guo, S.H. (2015) Isolation and Characterization of Oil-Degrading Microorganisms for Bench-Scale Evaluations of Autochthonous Bioaugmentation for Soil Remediation. Water Air Soil Pollution, 226, 272-281. https://doi.org/10.1007/s11270-015-2491-6

[5] Laorrattanasak, S., Rongsayamanont, W., Khondee, N., Paorach, N., Soonglerdsongpha, S., Pinyakong, O. and Luepromchai, E. (2016) Production and Application of Gordonia Westfalica GY40 Biosurfactant for Remediation of Fuel Oil Spill. Water Air Soil Pollution, 227, 325-337. https://doi.org/10.1007/s11270-016-3031-8

[6] Chu, W. and Kwan, C.Y. (2003) Remediation of Contaminated Soil by a Solvent/Surfactant System. Chemosphere, 53, 9-15. https://doi.org/10.1016/S0045-6535(03)00389-8

[7] Hamme, J.D., Singh, A. and Ward, O.P. (2003) Recent Advances in Petroleum Microbiology. Microbiology and Molecular Biology Reviews, 67, 503-549. https://doi.org/10.1128/MMBR.67.4.503-549.2003

[8] Medinabellver, J.I., Marın, P., Delgado, A., Rodríguezsánchez, A., Reyes, E., Ramos, J.L. and Marques, S. (2005) Evidence for In Situ Crude Oil Biodegradation after the Prestige Oil Spill. Environmental Microbiology, 7, 773-781, https://doi.org/10.1111/j.1462-2920.2005.00742.x

[9] April, T.M., Foght, J.M. and Currah, R.S. (2000) Hydrocarbon-Degrading Filamentous Fungi Isolated from Flare Pit Soils in Northern and Western Canada. Canadian Journal of Microbiology, 46, 38-49.

[10] Alsayegh, A., Alwahaibi, Y., Albahry, S., Elshafie, A., Albemani, A. and Joshi, S. (2015). Microbial Enhanced Heavy Crude Oil Recovery through Biodegradation Using Bacterial Isolates from an Omani Oil Field. Microbial Cell Factories, 14, 141-151. https://doi.org/10.1186/s12934-015-0330-5

[11] Leahy, J.G. and Colwell, R.R. (1990) Microbial Degradation of Hydrocarbons in the Environment. Microbiological Reviews, 54, 305-315.

[12] Li, B.M., Ruan, Z.Y. and Jiang, R.B. (2007) Screen and Identification of Oil Degrading Bacteria and Community Construction. Soil and Fertilizer Sciences in China, 3, 68-72.

[13] Zhao, B. and He, S.J. (2002) Microbiology Experiment. Science Press, Beijing.

[14] Sawadogo, A., Otoidobiga, H.C., Nitiema, L.W., Traore, A.S. and Dianou, D. (2014) Isolation and Characterization of Hydrocarbon-Degrading Bacteria from Wastewaters in Ouagadougou, Burkina Faso. Journal of Environmental Protection, 5, 1183-1196. https://doi.org/10.4236/jep.2014.512115

[15] Yang, Q., Wu, M.L., Cao, B.X., Cao, W.J. and Nie, M.Q. (2014) Isolation of Petroleum Degrading Strains and Determination Their Degrading and Gene Characteris- 
tics. Journal of Safety and Environment, 14, 187-192.

[16] Liu, H., Yao, J., Yuan, Z., Yuan, Z.M., Shang, Y.F., Chen, H.L., Wang, F., Masakorala, K., Yu, C., Cai, M., Blake, R.E. and Choi, M.M.F. (2014) Isolation and Characterization of Crude-Oil-Degrading Bacteria from Oil-Water Mixture in Dagang Oilfield, China. International Biodeterioration \& Biodegradation, 87, 52-59.

[17] Chen, C., Chen, S.F., Wang, J.Y., Mao, Z.Q., Zhou, B. and Wang, B. (2014) Isolation, Identification and the Biocontrol Potential of a Strain of Brevibacillus laterosporus. Microbiology China, 41, 2275-2282.

[18] Shida, O., Takagi, H., Kadowaki, K. and Komagata, K. (1996) Proposal for Two New Genera, Brevibacillus gen. nov. and Aneurinibacillusgen. nov. International Journal of Systematic Bacteriology, 46, 939-946. https://doi.org/10.1099/00207713-46-4-939

[19] Lima, D.F., Olivia, O.M.C.D., Geris, R.M.D.S. and Barreto, L.I.S. (2017) Isolation and Selection of Fungi for Degrading Saturated Hydrocarbons, Aromatic Hydrocarbons and NSO Compounds. Open Journal of Yangtze Gas and Oil, 2, 10-26. https://doi.org/10.4236/ojogas.2017.21002

[20] Battu, S. and Pottabathini, V. (2015) Hydrolytic Degradation Study of Lansoprazole, Identification, Isolation and Characterisation of Base Degradation Product. American Journal of Analytical, 6, 145-155. https://doi.org/10.4236/ajac.2015.62013

Submit or recommend next manuscript to OALib Journal and we will provide best service for you:

- Publication frequency: Monthly

- 9 subject areas of science, technology and medicine

- Fair and rigorous peer-review system

- Fast publication process

- Article promotion in various social networking sites (LinkedIn, Facebook, Twitter, etc.)

- Maximum dissemination of your research work

Submit Your Paper Online: Click Here to Submit

Or Contact service@oalib.com 